\title{
PROTECTION OF C57BL/10 MICE BY VACCINATION WITH ASSOCIATION OF PURIFIED PROTEINS FROM Leishmania (Leishmania) amazonensis
}

\author{
Ana Mariela MORA, Wilson MAYRINK, Roberto Teodoro DA COSTA, Carlos Alberto DA COSTA, Odair GENARO \& Evaldo NASCIMENTO
}

\begin{abstract}
SUMMARY
In the past few years, induction of protective immunity to cutaneous leishmaniasis has been attempted by many researchers using a variety of antigenic preparations, such as living promastigotes or promastigote extracts, partially purified, or defined proteins. In this study, eleven proteins from Leishmania (Leishmania) amazonensis (LLa) with estimated molecular mass ranging from 97 to $13.5 \mathrm{kDa}$ were isolated by polyacrylamide gel electrophoresis and electro-elution. The proteins were associated as vaccine in different preparations with gp63 and BCG (Bacilli Calmette-Guérin). The antigenicity of these vaccines was measured by their ability to induce the production of IFN- $\gamma$ by lymphocyte from subjects vaccinated with Leishvacin ${ }^{\circledR}$. The immunogenicity was evaluated in vaccinated mice. C57BL/10 mice were vaccinated with three doses of each vaccine consisting of $30 \mu \mathrm{g}$ of each protein at 15 days interval. One hundred $\mu \mathrm{g}$ of live BCG was only used in the first dose. Seven days after the last dose, they received a first challenge infection with $10^{5}$ infective promastigotes and four months later, a second challenge was done. Two months after the second challenge, $42.86 \%$ of protection was obtained in the group of mice vaccinated with association of proteins of gp $63+46+22 \mathrm{kDa}$, gp63+13.5+25+42kDa, gp63+46+42kDa, gp63+66kDa, and gp63+97kDa; $57.14 \%$ of protection was demonstrated with gp63+46+97+13.5kDa, gp63+46+97kDa, gp63+46+33kDa, and $71.43 \%$ protection for gp63 plus all proteins. The vaccine of gp63+46+40kDa did not protect the mice, despite the good specific stimulation of lymphocytes $(\mathrm{LSI}=7.60)$ and $10.77 \mathrm{UI} / \mathrm{ml}$ of IFN$\gamma$ production. When crude extract of $L$. (L.) amazonensis was used with BCG a $57.14 \%$ of protection was found after the first challenge and $28.57 \%$ after the second, the same result was observed for gp63 along with BCG. The data obtained with the vaccines can suggest that the future vaccine probably have to contain, except the $40 \mathrm{kDa}$, a cocktail of proteins that would protect mice against cutaneous leishmaniasis.
\end{abstract}

KEYWORDS: Leishmania; Proteins; Mice; Vaccine.

\section{INTRODUCTION}

Leishmania (Leishmania) amazonensis is a parasitic protozoon that causes localized cutaneous lesions and in some cases, diffuse cutaneous lesions (LAINSON, 1983). Cutaneous lesions develop in one or two months as a hard nodule that, later, develop into an open lesion that secrets serous liquid, and secondary infection becomes established in most of the cases. Diffuse lesions are characterized by large histiocytomalike nodules disseminated in the skin containing numerous parasites and by deficient cellular immunity, probably due the immunosuppression (CONVIT et al., 1993; PETERSEN et al., 1982; SHAW \& LAINSON, 1975).

The induction of protective immunity against cutaneous leishmaniasis is an important strategy for disease control. In the past, experiments to protect mice against cutaneous leishmaniasis have been conducted using parasite extract (BARRAL-NETO et al., 1987; FROMMEL et al., 1988; LIEW et al., 1987; MITCHELL et al., 1985; MODDABER, 1989;
SCOTT et al., 1987) and a single antigen such as gp63 (RUSSELL \& ALEXANDER, 1988) or lipophosphoglycan (HANDMAN \& MITCHELL, 1985).

NASCIMENTO et al. (1990) reported the $90 \%$ correlation between Leishmania skin test and induction of in vitro cellular immune response by PBL from vaccinated subjects with Leishvacin ${ }^{\circledR} 5$ or Leishvacin ${ }^{\circledR} 6$ (vaccines with 5 or 6 Leishmania stocks). First attempts to identify the protective antigens from Leishvacin ${ }^{\circledR}$ by immunoprecipitation with homologous sera, revealed the presence of 8 major immunogenic components of the Leishvacin ${ }^{\circledR}$ with estimated masses ranging from 160 to $13.5 \mathrm{kDa}$ including gp63.

The host immune response to Leishmania infections is the main factor that controls the outcome of the disease (LIEW et al., 1987; LOCKSLEY \& LOUIS, 1992; SCOTT, 1989). In mice, susceptibility and resistance to Leishmania major have been correlated with the preferential stimulation of the different $\mathrm{CD}^{+} \mathrm{T}$ cell subsets, Th1 and Th2, and the

Supported by PADCT/CNPq/Biotecnology grant \# 620252/91-0

Department of Parasitology, Institute of Biological Sciences, Federal University of Minas Gerais.

Correspondence to: Dr. Evaldo Nascimento, Av. Antonio Carlos 6627, Caixa Postal 486, 31270-901 Belo Horizonte, MG, Brazil. E mail: evaldo@ mono.icb.ufmg.br 


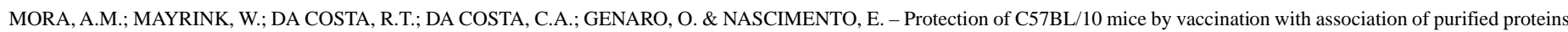
from Leishmania (Leishmania) amazonensis. Rev. Inst. Med. trop. S. Paulo, 41(4): 243-248,1999.

type of cytokines that they produce. Protection is associated with cells that secrete interleukin-2 (IL-2) and interferon- $\gamma$ (IFN- $\gamma$ ) (LOCKSLEY \& LOUIS, 1992; BRETSCHER et al., 1992; SCOTT, 1991), whereas the expansion of the Th2 cells that produce IL-4 and IL-10 exacerbates the disease (CHATELAIN et al., 1992; HEINZEL et al., 1989; SADICK et al., 1990).

A Th1 response is detected in patients with active cutaneous or mucocutaneous leishmaniasis and a predominant Th2 response occurs in patients with the diffuse form of the disease (CÁCERES-DITTMAR et al., 1993; PIRMEZ et al., 1993). CD8 ${ }^{+}$T cells are also able to produce IFN- $\gamma$ and evidences have been raised on the protective role played by these cells (CHAN, 1993; DA CRUZ et al., 1993; MULLER et al., 1991; NASCIMENTO et al., 1990).

Other cytokines such as IL-12 (AFONSO et al., 1994; SYPEK et $a l ., 1993)$ and the tumor necrosis factor $\alpha$ (TNF- $\alpha$ ) (STENGER et al., 1994; TITUS et al., 1989) are also crucial to the establishment of a protective response in experimental leishmaniasis whereas an increased expression of transforming growth factor $\beta$ (TGF- $\beta$ ) is associated with susceptibility of infection (BARRAL-NETO et al., 1993).

CARDOSO et al. (submitted) have previously purified the proteins of 42, 46, 63, 66, 73, 87, 97, and 160kDa from Leishvacin ${ }^{\circledR}$ (MAYRINK et al., 1979). In the vaccination protocol each mouse received three doses of $30 \mu \mathrm{g}$ of each protein plus Corynebacterium parvum, as adjuvant, at 15 day intervals. Six months after challenge infection with $L$. (L.) amazonensis the levels of protection ranged from $57.1 \%$ to $20 \%$.

The aim of the present study was to identify immunogenicity of association of proteins from $L$. (L.) amazonensis through their abilities to induce IFN- $\gamma$ synthesis, stimulation of lymphocyte proliferation and also to protect C57BL/10 mice against infection by L. (L.) amazonensis.

\section{MATERIAL AND METHODS}

Parasite stock. The stock of L. (L.) amazonensis (IFLA/BR/67/PH8) was maintained in the Department of Parasitology, Institute of Biological Sciences of the Federal University of Minas Gerais, Brazil, by continuous passages in hamster. Infective promastigotes and crude extract were obtained by isolation of parasites from hamsters lesions following inoculation in NNN/LIT biphasic medium. Cultures were maintained at $23{ }^{\circ} \mathrm{C}$ for 12 days.

Antigen preparation. Promastigotes from stationary phase were grown in scaled up culture at $23{ }^{\circ} \mathrm{C}$ for seven days using a bottle with acellular LIT (CAMARGO, 1964). The parasites $\left(10^{8}\right.$ promastigotes per tube) were pelleted by centrifugation in $1200 \mathrm{~g}$ for $10 \mathrm{~min}$ at $4{ }^{\circ} \mathrm{C}$. The pellet of promastigotes was washed three times in PBS, and maintained at $-85^{\circ} \mathrm{C}$ until use.

Protein purification. The pellet of promastigotes was treated by an addition of $500 \mu \mathrm{L}$ of buffer [ $1 \mathrm{mM}$ Tris- $\mathrm{HCl}(\mathrm{pH} 8.0), 137 \mathrm{mM} \mathrm{NaCl}$, $2 \mathrm{mM}$ EDTA, $1 \mathrm{mM}$ phenylmethylsulfonyl fluoride, $10 \mathrm{mM} \mathrm{1,10-}$ phenanthroline], and were vigorously mixed. One $\mathrm{ml}$ of sample buffer (125M Tris- $\mathrm{HCl}, 4 \%$ SDS, $10 \% 2$ - mercaptoethanol, $20 \%$ glycerol) was added, mixed and boiled for $10 \mathrm{~min}$. The crude extract was loaded in $10 \%$ polyacrylamide gel, as described previously by NASCIMENTO et al. (1990). After electrophoresis, protein bands ranging from 13.5 to $97 \mathrm{kDa}$ were visualized. The bands were excised from the gel, and submitted to electro-elution, followed by dialysis against PBS pH 7.2. The dialysis bags were transferred to Petri dishes and cover by sucrose to concentrate the protein. Another dialysis, in the same conditions, was performed to remove residual sucrose. Protein concentrations were determined according LOWRY et al. (1951). The proteins were associated with gp63 for in vitro studies and for vaccination experiments.

Induction and assay for gamma interferon. To determine if each purified protein was able to induce the synthesis of IFN- $\gamma$, peripheral blood leukocytes (PBL) from seven vaccinated subjects with Leishvacin ${ }^{\circledR}$ were separated by Ficoll/Hypaque gradient centrifugation as described by NASCIMENTO et al. (1990). The IFN- $\gamma$ response was assayed in triplicate culture. A total of $20 \mu \mathrm{g}$ of antigen per ml of crude extract or association of proteins was used for PBL stimulation. The culture was incubated for three days at $37{ }^{\circ} \mathrm{C}$ in a $5 \% \mathrm{CO}_{2}$ incubator. After this time, the supernatant of each stimulated culture was pooled and the level of IFN- $\gamma$ measured by ELISA following the instructions of the manufacture (Holland Biotechnology CO). The results were expressed in UI/ml.

Vaccination of mice. Female imbred C57BL/10 mice 8 to 12 weeks old were obtained from animal facilities at Federal University of Minas Gerais, Minas Gerais State, Brazil. Each group of seven mice was vaccinated subcutaneously according to FERNANDES et al., (1997) into the left footpad with three doses of combined proteins with $30 \mu \mathrm{g}$ each at 15 days intervals with BCG (Bacilli Calmette-Guérin - Fundação Athaulpho de Paiva, Rio de Janeiro, Brazil) as an adjuvant, in the first dose. Group of control animals received $100 \mu \mathrm{g}$ of live BCG, $100 \mu \mathrm{l}$ of PBS (phosphate buffer saline) or $100 \mu \mathrm{g}$ of Leishvacin ${ }^{\circledR}$ in $100 \mu \mathrm{l}$ of PBS, respectively, following the same immunization scheme. Seven days after the last vaccination, each animal was challenged with $10^{5}$ promastigotes from $L$. (L.) amazonensis.

Challenge infection. Infective promastigotes were obtained as described in "Parasite stock". After 12 days of cultivation at $23^{\circ} \mathrm{C}$ the promastigotes were counted in a Neubauer chamber. Vaccinated mice or control groups received the first challenge of $10^{5}$ infective promastigotes seven days after the last dose of the vaccine. The injection was done in the left footpad. The second challenge was done in the same place 143 days after the first one. The development of lesions was monitored at 15 days interval, during 203 days after the first challenge.

Lymphocyte stimulation index (LSI). Three months after the second challenge the animals were sacrificed and the spleens were transferred to Petri dishes containing RPMI 1640 (Gibco, USA) medium. The spleens were homogenized and the cells were counted in a Neubauer chamber. For vaccinated and control C57BL/10 mice $0.5 \times 10^{6}$ cells/well were used. The cells were stimulated with each association of proteins in the concentration as used for IFN- $\gamma$ assay. They were maintained at $37^{\circ} \mathrm{C}$ in a $5 \% \mathrm{CO}_{2}$ incubator for 5 days. Five micrograms per $\mathrm{ml}$ of PHA was used as mitogen. The cells were then pulsed with $0.5 \mu \mathrm{Ci}$ of $\left[{ }^{3} \mathrm{H}\right]$ thymidine (specific activity, $6.7 \mathrm{Ci} / \mathrm{mMol}$ : Dupont, NEN Research Products, Boston, Mass, USA) per culture per 18 hours, harvested, and processed for the scintillation counter (BetaRack, Pharmacia, Sweden). The magnitude of proliferation was determinated by calculating a Lymphocyte Stimulation Index (LSI) for each vaccinated subject by using the following formula: LSI $=$ the average of mean counts per minute of triplicate cultures - 


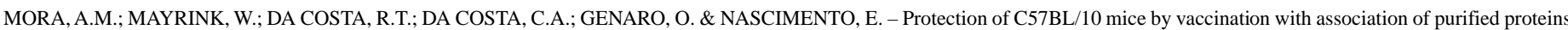
from Leishmania (Leishmania) amazonensis. Rev. Inst. Med. trop. S. Paulo, 41(4): 243-248,1999.

machine background/average of mean triplicate unstimulated cultures machine background (NASCIMENTO et al., 1990).

Vaccine efficacy. Clinical observations of the animals and lesion development were evaluated during 203 days after the first and second challenge infections at seven day interval. Lesion measurements were done at 15 days intervals with a micrometer (Mitutoyo do Brasil). The results were expressed as percentages of protection $[\%$ protection $=$ (number of animals without lesion / number of animals of the group) $x$ 100]. The animals were sacrificed and smear from footpad skin was Giemsa stained for the presence of parasites. For histopathological examinations a biopsy was taken at the site of the infection, biopsy fragments were fixed in $10 \%$ formalin, washed in water for 4 hours, dehydrated and embedded in paraffin, cut (3-4 $\mu \mathrm{m}$ thick) and stained with hematoxylin and eosin for optical microscope examination (TAFURI et al., 1996).

\section{RESULTS}

The proteins of estimated molecular mass of 13.5, 22, 25, 33, 40, $42,46,63,66,85$, and 97kDa were purified from $L$. (L.) amazonensis using SDS-PAGE and electro-elution (Figure 1), and were associated as vaccines as shown in Table 1 .

In order to know if each association of proteins is able to induce the synthesis of IFN- $\gamma$, peripheral blood leukocytes (PBL) from vaccinated subjects with Leishvacin ${ }^{\circledR}$ (NASCIMENTO et al., 1990) was evaluated. The results showed that the levels of IFN- $\gamma$ in the supernatant of cultures were not statistically significant $(\mathrm{p}>0.05$ ) ranging from $19.14 \mathrm{UI} / \mathrm{ml}$ to $10.08 \mathrm{U} / \mathrm{ml}$. Levels of IFN- $\gamma$ obtained with the vaccines gp $63+46+97 \mathrm{kDa}$, gp $63+46+22 \mathrm{kDa}, \quad$ gp $63+46+97+13.5 \mathrm{kDa}, \quad \mathrm{gp} 63+46+33 \mathrm{kDa}$, gp63+63+23.5+25+42kDa, gp63+66kDa, gp63+97+85kDa, gp63 plus all proteins were always higher in comparison with $13.32 \mathrm{UI} / \mathrm{ml}$ obtained with the vaccine $L$. L. amazonensis crude extract. Using gp63+46+13.5kDa, gp63+46+40kDa, gp63+46+42kDa, gp63+97kDa, gp63 the levels of IFN-y were bellow those obtained with $L$. (L.) amazonensis crude extract and above those observed for BCG (Table 1).

The vaccine gp63+46+13.5kDa, gp63+46+22KDa, gp63+85+97KDa, and gp63 showed similar LSI in comparison with 10.80 of LSI obtained

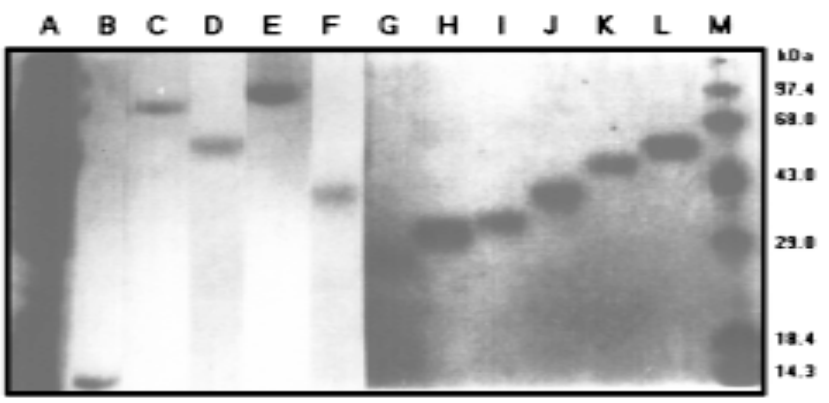

Fig. 1 - Proteins in 10\% polyacrylamide gel electrophoresis (SDS-PAGE) purified from Leishmania (Leishmania) amazonensis. A - crude extract of L. (L.) amazonensis (LLa), B protein of $13.5 \mathrm{kDa}, \mathrm{C}-85 \mathrm{kDa}, \mathrm{D}-66 \mathrm{kDa}, \mathrm{E}-97 \mathrm{kDa}, \mathrm{F}-22 \mathrm{kDa}, \mathrm{G}-25 \mathrm{kDa}, \mathrm{H}-33$ $\mathrm{kDa}, \mathrm{I}-40 \mathrm{kDa}, \mathrm{J}-42 \mathrm{kDa}, \mathrm{K}-46 \mathrm{kDa}, \mathrm{L}-\mathrm{gp} 63$, M - molecular weight markers in kDa.
Table 1

Gamma interferon (IFN- $\gamma$ ) production by human peripheral blood leukocytes from vaccinated subjects and lymphocyte stimulation index (LSI) from vaccinated $\mathrm{C} 57 \mathrm{BL} / 10$ mice by vaccine stimulation

\begin{tabular}{clrr}
\hline $\begin{array}{c}\text { Group of } \\
7 \text { mice }\end{array}$ & $\begin{array}{l}\text { Vaccine components } \\
(\mathrm{kDa})\end{array}$ & $\begin{array}{c}\text { IFN- } \gamma \\
(\mathrm{U} / \mathrm{ml})\end{array}$ & $\begin{array}{c}\text { LSI } \\
(\text { Ratio })\end{array}$ \\
\hline 1 & gp63+46+97+BCG & 15.54 & 8.00 \\
2 & gp63+46+13.5+BCG & 11.23 & 10.00 \\
3 & gp63+46+22+BCG & 16.80 & 10.40 \\
4 & gp63+46+97+13.5+BCG & 13.56 & 9.60 \\
5 & gp63+46+33+BCG & 19.14 & 11.70 \\
6 & gp63+46+40+BCG & 10.77 & 7.60 \\
7 & gp63+46+42+BCG & 12.55 & 9.00 \\
8 & gp63+13.5+25+42+BCG & 13.81 & 7.80 \\
9 & gp63+66+BCG & 14.00 & 7.20 \\
10 & gp63+97+BCG & 11.23 & 8.30 \\
11 & gp63+85+97+BCG & 15.82 & 10.10 \\
12 & gp63+all proteins+BCG & 14.61 & 8.50 \\
13 & gp63+BCG & 10.08 & 10.20 \\
14 & LLa+BCG & 13.32 & 10.80 \\
15 & BCG & 9.16 & 5.10 \\
16 & PBS & 5.11 & 1.50 \\
\hline
\end{tabular}

LLa: crude extract of $L$. (L.) amazonensis. 11 proteins:13.5, 22, 25, 33, 40, 42, 46, 63, 66, 85, 97 kDa, BCG: Bacillus Calmett-Guérin. LSI - average of lymphocyte stimulation index. PHA stimulation was $62486 \mathrm{cpm}$.

Table 2

Efficacy of vaccines constituted with combination of purified proteins from Leishmania (Leishmania) amazonensis to protect C57BL/10 mice after two challenge infections with homologous $10^{5}$ infective promastigotes

\begin{tabular}{|c|c|c|c|}
\hline \multirow[b]{2}{*}{$\begin{array}{l}\text { Group of } \\
7 \text { mice }\end{array}$} & \multirow[b]{2}{*}{$\begin{array}{l}\text { Vaccine components } \\
(\mathrm{kDa})\end{array}$} & \multicolumn{2}{|c|}{ Efficacy $(\%)$} \\
\hline & & $\begin{array}{l}143 \text { days } \\
\text { after first } \\
\text { challenge }\end{array}$ & $\begin{array}{c}60 \text { days } \\
\text { after second } \\
\text { challenge }\end{array}$ \\
\hline 1 & gp63+46+97+BCG & 57.14 & 57.14 \\
\hline 2 & gp63+46+13.5+BCG & 57.14 & 28.57 \\
\hline 3 & gp63+46+22+BCG & 57.14 & 42.86 \\
\hline 4 & gp63+46+97+13.5+BCG & 57.14 & 57.14 \\
\hline 5 & gp63+46+33+BCG & 57.14 & 57.14 \\
\hline 6 & gp $63+46+40+B C G$ & 00.00 & 00.00 \\
\hline 7 & gp63+46+42+BCG & 42.86 & 42.86 \\
\hline 8 & gp $63+13.5+25+42+B C G$ & 42.86 & 42.86 \\
\hline 9 & gp63+66+BCG & 42.86 & 42.86 \\
\hline 10 & gp63+97+BCG & 42.86 & 42.86 \\
\hline 11 & gp63+85+97+BCG & 57.14 & 28.57 \\
\hline 12 & gp63+all proteins $+\mathrm{BCG}$ & 71.43 & 71.43 \\
\hline 13 & gp63+BCG & 57.14 & 28.57 \\
\hline 14 & $L L a+B C G$ & 57.14 & 28.57 \\
\hline 15 & $\mathrm{BCG}$ & 14.29 & 00.00 \\
\hline 16 & PBS & 00.00 & 00.00 \\
\hline
\end{tabular}

LLa: crude extract of $L$. (L.) amazonensis. 11 proteins:13.5, 22, 25, 33, 40, 42, 46, 63, 66, 85, 97 kDa, BCG: Bacillus Calmett-Guérin. 
with $L$. (L.) amazonensis crude extract. Indeed, the vaccine of gp63+46+33kDa showed higher index of T cell stimulation (Table 1).

The lesions start to grow one month after first challenge. The mice were considered protected four months after the second challenge. After two months the presence of lesions was not observed in all vaccinated mice (Figure 2). The presence of parasites in the footpad lesions was evaluated by histopathological studies under microscope examination in serial cut of the tissue. Parasites were not found in most animals. Intracellular and extracellular amastigotes were found in all mice belonging to the control groups (data not shown).

The vaccination of C57BL/10 mice with these vaccines resulted in different levels of protection (Table 2). But, surprising results were
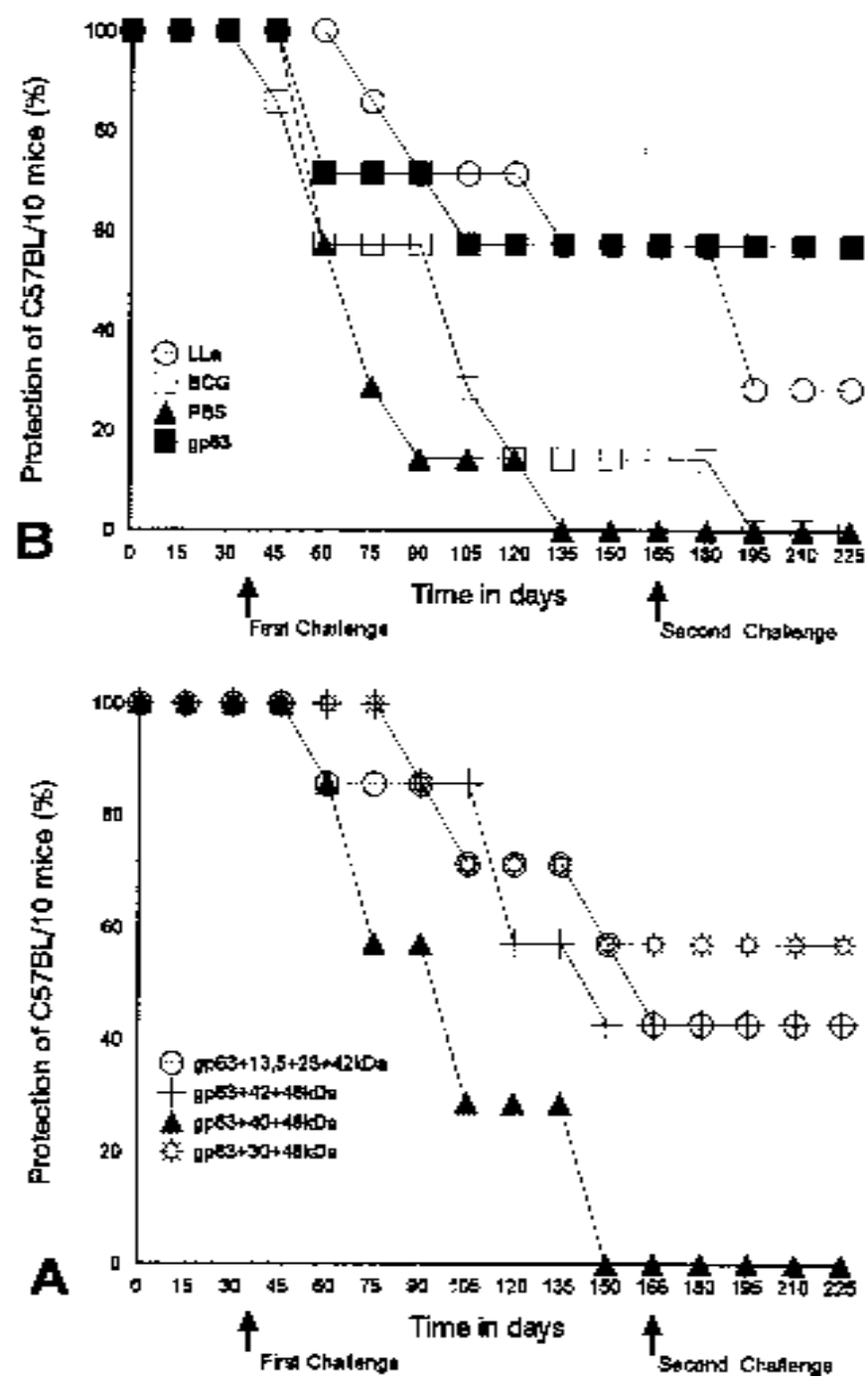

observed with the vaccine of gp63+46+40kDa that did not protect the mice (Figure 2), despite good lymphocyte proliferation $(\mathrm{LSI}=7.60)$ and $10.77 \mathrm{UI} / \mathrm{ml}$ of IFN- $\gamma$ production. Mice injected with BCG alone or with PBS developed progressive infections in the footpad. The group injected with BCG $14.29 \%$ of the mice did not develop lesions following the first challenge, but all became infected after the second challenge (Figure 2A).

The efficacy of the vaccines to protect C57BL/10 mice can be observed in Table 2. The lowest protection $(28.57 \%)$ was obtained using the vaccine gp63+46+13.5kDa, gp63+85+97kDa, gp63kDa or LLa. Good protection $(42.86 \%)$ was obtained with gp $63+46+22 \mathrm{kDa}$, gp $63+46+42 \mathrm{kDa}, \operatorname{gp} 63+13.5+25+42 \mathrm{kDa}, \mathrm{gp} 66+66 \mathrm{kDa}$, and gp63+97kDa, but very good protection $(57.14 \%)$ was obtained using
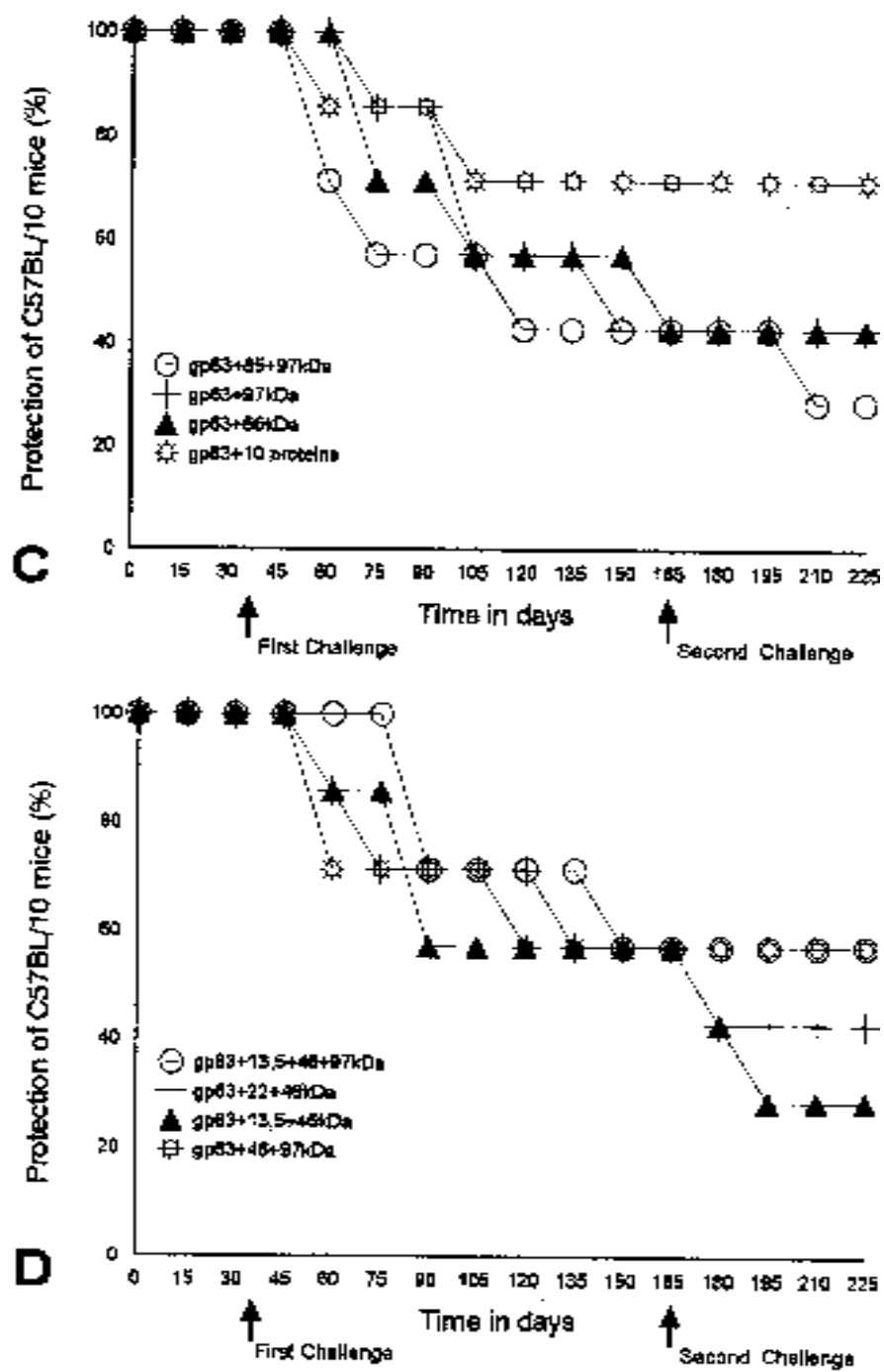

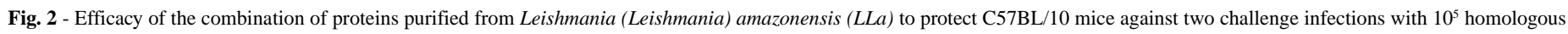

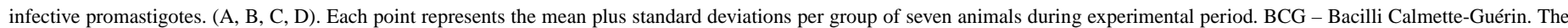
results are expressed as percentages of protection (see Material and Methods). 


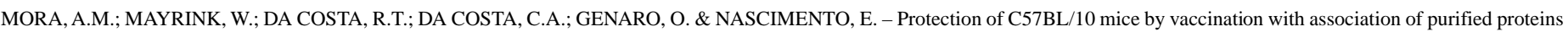
from Leishmania (Leishmania) amazonensis. Rev. Inst. Med. trop. S. Paulo, 41(4): 243-248,1999.

gp63+46+97kDa, gp63+13.5+85+97kDa or gp63+46+33kDa. The best protection $(71.43 \%)$ was obtained using the vaccine constituted by gp63 plus all proteins and BCG (Table 2).

\section{DISCUSSION}

In experimental studies using animal models or in human trials, it is clear that resolution of the lesions and resistance to Leishmania infections require the induction of effective cell-mediated immunity able to activate efficiently the macrophages to kill the parasite. T cells and INF- $\gamma$ production are mainstays of this protective response (SCOTT et al., 1987; CHAMPSI \& McMAHON-PRATT, 1988; CÁCERES-DITTMAR et al., 1993; CHAN, 1993). Antigens inducing this type of response, especially in human primed $\mathrm{T}$ cells can be considered potential vaccine candidates. Therefore, the INF- $\gamma$ production by human primed $\mathrm{T}$ cells, and lymphocyte proliferation of immunized mice can provide a reliable screening of such antigens.

Reports from different laboratories have shown that purified protein and recombinant Leishmania antigens, such as the gp46, gp63 and 33kDa, can induce partial protection against Leishmania infection in animal models (CHAMPSI \& McMAHON-PRATT, 1988; RUSSELL \& ALEXANDER, 1988; BUTTON \& McMASTER, 1988; FERNANDES et al., 1997).

In this report, we demonstrated that at least five $(13.5,33,46,63$ and $97 \mathrm{kDa}$ ) out of eleven proteins from $L$. (L.) amazonensis had the ability to stimulate lymphocytes in C57BL/10 vaccinated mice, induce IFN- $\gamma$ production of PBL from Leishvacin ${ }^{\circledR}$ vaccinated subjects (Table 1 ), and also partially protected mice against two challenge infections by L. (L.) amazonensis (Table 2). As previously observed, gp63 is one of the major components of Leishvacin ${ }^{\circledR}$ (NASCIMENTO et al., 1990), and by all of the parameters analyzed, it elicited responses equivalent to L. (L.) amazonensis crude extract, and induced $57.14 \%$ of protection of mice after first challenge and $28.57 \%$ after the second one.

In contrast, the association of gp $63+46+40 \mathrm{kDa}$ was not able to induce protective immunity in vaccinated mice, but was able to stimulate lymphocyte proliferation with LSI of 7.60 and $10.77 \mathrm{U} / \mathrm{ml}$ of INF- $\gamma$ production. These data suggest that the $40 \mathrm{kDa}$ maybe is an immunosuppressive protein and with inhibitory effect on $\mathrm{T}$ cell proliferation, resulting in an absence of immunity against this infection. If this is true, the vaccine that stimulates higher levels of IFN- $\gamma$ and LSI probably indicate a great immunological ability to protect mice (Table 1, 2, Figure 2A).

The proteins of $22,25,42$, and $66 \mathrm{kDa}$ stimulated IFN- $\gamma$ production and stimulated mice T cells (Table 1 ), but only $42.86 \%$ of protection as observed against the second infective challenge (Table 2). The greatest protection $(71.43 \%$ ) was obtained using the vaccine constituted by all proteins. In addition, a correlation was observed between synthesis of IFN- $\gamma$, lymphocyte proliferation and protection (Table 1,2 ).

Finally, the present results with different associations of $L$. (L.) amazonensis proteins and BCG strongly suggest that an efficient vaccine against cutaneous leishmaniasis, will have to contain a cocktail of immunogenic proteins.

\section{RESUMO}

\section{Proteção de camundongos C57BL/10 vacinados por vacinas contituidas pelas combinações de proteínas purificadas de Leishmania (Leishmania) amazonensis}

A indução de imunidade no homem contra a leishmaniose cutânea tem sido estudada por vários pesquisadores usando uma grande variedade de preparações antigênicas, como: promastigotas vivas ou atenuadas, extratos de promastigotas, antígenos parcialmente purificados e proteínas puras. Neste trabalho foram isoladas 11 proteínas de $L$. (L.) amazonensis com pesos moleculares variando de 13.5 a $97 \mathrm{kDa}$ por eletroforese em gel de poliacrilamida e por eletroeluição. Estas proteínas foram combinadas em diferentes preparações vacinais com gp63 e BCG. As vacinas foram avaliadas in vitro quanto à capacidade de estimular linfócitos de pessoas vacinadas com Leishvacin ${ }^{\circledR}$ a produzirem IFN- $\gamma$ e a estimularem a proliferação de linfócitos de camundongos vacinados. Assim, camundongos C57BL/10 foram vacinados em intervalos de 15 dias com três doses de cada vacina contendo $30 \mu \mathrm{g}$ de cada proteína. $100 \mu \mathrm{g}$ de BCG foram usados somente na primeira dose. Sete dias após a última dose os animais receberam a primeira infecção desafiado com $10^{5}$ promastigotas infectantes e um segundo desafio foi administrado 143 dias após, com o mesmo número de parasitas. Sessenta dias após o segundo desafio, proteções de $42,86 \%$ foram obtidas com as vacinas constituídas de gp63+46+22kDa, gp63+13.5+25+42kDa, gp63+46+42kDa, gp63+66kDa e gp63+97kDa; 57,14\% de proteção foi obtido com a vacina gp63+46+97kDa, gp63+46+97+13.5kDa, gp63+46+33kDa, e 71,43\% com a vacina constituída de gp63 mais todas as proteínas. Em contraste, a vacina gp63+46+33kDa não induziu proteção nos camundongos vacinados, indicando que possivelmente a proteína de 40kDa induziu a uma atividade imunossupressora da resposta imunoprotetora. Estes resultados sugerem que uma futura vacina contra a leishmaniose cutânea deverá conter, excluindo-se a proteína de $40 \mathrm{kDa}$, um coquetel de proteínas imunogênicas indutoras de proteção de camundongos contra a leishmaniose cutânea.

\section{REFERENCES}

1. AFONSO, L.C.C.; SCHARTON, T.M.; VIEIRA, L.Q. \& WYSOCKA, M. - The adjuvant effect of interleukin-12 in a vaccine against Leishmania major. Science, 263: 235237, 1994.

2. BARRAL-NETO, M.; REED, S.G.; SADIGURSKY, M. \& SONNEUFELD, R. - Specific immunization of mice against Leishmania amazonensis using solubilized promastigotes. Clin. exp. Immunol., 139: 11-19, 1987.

3. BARRAL-NETO, M.; BARRAL, A.; BROWNELL, C.E. \& SKEIKY, Y.A.W. Transforming growth factor- $\beta$ in leishmanial infection. Science, 257: 545-548, 1993

4. BRETSCHER, P.A.; WEI, G.; MENON, B. \& BIELEFELDT, H. - Establishment of stable, cell mediated immunity that makes "susceptible" mice resistant to Leishmania major. Science, 257: 539-542, 1992.

5. BURNS, J.M.; SCOTT, J.M.; CARVALHO, E.M. et al. - Characterization of membrane antigen of Leishmania amazonensis that stimulates human immune responses. J. Immunol., 146: 742-748, 1991 .

6. BUTTON, L.L. \& MCMASTER, W.R. - Molecular cloning of the major surface antigens of Leishmania. J. exp. Med., 167: 724-729, 1988.

7. CÁCERES-DITTMAR, G.; TAPIA, F.J.; SANCHES, M.A. et al. - Determination of the cytokine profile in American cutaneous leishmaniasis using the polymerase chain reaction. Clin. exp. Immunol., 91: 500-505, 1993. 
MORA, A.M.; MAYRINK, W.; DA COSTA, R.T.; DA COSTA, C.A.; GENARO, O. \& NASCIMENTO, E. - Protection of C57BL/10 mice by vaccination with association of purified proteins from Leishmania (Leishmania) amazonensis. Rev. Inst. Med. trop. S. Paulo, 41(4): 243-248,1999.

8. CAMARGO, E.P. - Growth differentiation in Trypanosoma cruzi: origin of metacyclic trypanosomes in liquid media. Rev. Inst. Med. trop. S. Paulo, 6: 93-100, 1964

9. CARDOSO, S.A.; MAYRINK, W.; FERNANDES, A.P. et al. - Identification of protective proteins from vaccine against cutaneous leishmaniasis (Leishvacin ${ }^{\hat{a}}$ ). Mem. Inst. Oswaldo Cruz (submitted in July,1998).

10. CHAMPSI, J. \& McMAHON-PRATT, D. - Membrane glycoprotein M-2 protects against Leishmania amazonensis infection. Infect. Immun., 52: 3272-3279. 1988.

11. CHAN, M.M. - T cell response in murine Leishmania mexicana amazonensis infection. Production of interferon-g by CD8+ T cells. Europ. J. Immunol., 23: 1181-1184, 1993.

12. CHATELAIN, R.; VARKILA, K. \& COFFMAN, R.L. - IL-4 induces a Th2 response in Leishmania major-infected mice. J. Immunol., 148: 1182-1187, 1992.

13. CONVIT, J.; ULRICH, M. \& FERNANDEZ, C.T.- The clinical and immunological spectrum of American cutaneous leishmaniasis. Trans. roy. Soc. trop. Med. Hyg., 87: 444-448, 1993.

14. DA CRUZ, A.; CONCEIÇÃO-SILVA, F.; BERTHO, A.L. \& COUTINHO, S.G. Leishmania-reactive $\mathrm{CD}^{+}$and $\mathrm{CD} 8^{+} \mathrm{T}$ cells associated with the cure of human cutaneous leishmaniasis. Infect. Immun., 62: 2614-2618, 1993.

15. FERNANDES, A.P.; HERRERA, E.C.; MAYRINK, W. et al. - Immune responses induced by a Leishmania (Leishmania) amazonensis recombinant antigen in mice and lymphocytes from vaccinated subjects. Rev. Inst. Med. trop. S. Paulo, 39: 71-78, 1997.

16. FROMMEL, D.; OGUNKOLADE, B.W.; VOULDOUKIS, I. \& MOUNJOUR, L. Vaccine-induced immunity against cutaneous leishmaniasis in Balb/c mice. Infect. Immun., 56: 843-848, 1988 .

17. GAZZINELLI, R.T.; BALAS, S.; STEVENS, R. et al. - HIV infection suppress type lymphokine and IL-12 responses to Toxoplasma gondii, but fails to inhibit the synthesis of other parasite-induced monokines. J. Immunol., 55: 1565-1574, 1994.

18. HANDMAN, E. \& MITCHELL, G.F. - Immunization with leishmania receptors for macrophages protects mice against cutaneous leishmaniasis. Proc. nat. Acad. Sci. (Wash.), 82: 5910-5914. 1985

19. HEINZEL, F.P.; SADICK, M.D.; HOLADAY, B.J.; COFFMAN, R.L. \& LOCKSLEY, R.M. - Reciprocal expression of interferon gamma or interleukin-4 during the resolution or progression of murine leishmaniasis. Evidence for expansion of distinct helper T cell subsets. J. exp. Med., 169: 59-72, 1989.

20. LAINSON, R. - The American leishmaniases: some observations on their ecology and epidemiology. Trans. roy. Soc. trop. Med. Hyg., 77: 569-596, 1983.

21. LIEW, F.Y. - Cell-mediated immunity in experimental cutaneous leishmaniasis. Parasit. today, 2: 264-266, 1986.

22. LIEW, F.Y.; HODSON, K. \& LELCHUK, J. - Prophylactic immunization against experimental leishmaniasis. VI. Comparison of protective and disease promoting T cells. J. Immunol., 139: 3112-3117, 1987.

23. LOCKSLEY, R.M. \& LOUIS, J.A. - Immunology of leishmaniasis. Curr. Opin. Immunol., 4: 413-416, 1992.

24. LOWRY, O.H.; ROSEMBROUGH, N.J.; FARR, L. \& RANDALL, R.J. - Protein measurement with the phenol folin reagent. J. biol. Chem., 193: 265-275, 1951.

25. MAYRINK, W.; DA COSTA, C.A.; MAGALHÃES, P.A. et al. - A field trial of a vaccine against American dermal leishmaniasis. Trans. roy. Soc. trop. Med. Hyg., 73: $385-387,1979$.

26. McMAHON-PRATT, D.; RODRIGUEZ, D.; RODRIGUEZ, R.J. et al. - Recombinant vaccinia viruses expressing GP46/M2 protect against Leishamnia infection. Infect. Immun., 61: 3351-3359, 1993.
27. MITCHELL, G.; HANDMAN, E. \& SPITHILL, H. - Examination of variable in the vaccination of mice against cutaneous leishmaniasis using living avirulent cloned lines and killed promastigotes of Leishmania major. Int. J. Parasit., 15: 667-684, 1985 .

28. MODDABER, F. - Experiences with vaccines against cutaneous leishmaniasis of men and mice. Parasitology, 98: 549-560, 1989.

29. MULLER, I.; PEDRAZINI, T.; KROPF, P. et al. - Establishment of resistance of $L$ major infection in susceptible $\mathrm{Balb} / \mathrm{c}$ mice requires parasite-specific $\mathrm{CD} 8{ }^{+}$cells. Int. Immunol., 3: 587-597, 1991.

30. NASCIMENTO, E.; MAYRINK, W.; DA COSTA, C.A. et al. - Vaccination of humans against cutaneous leishmaniasis: cellular and humoral immune responses. Infect. Immun., 58: 2198-2203, 1990.

31. PETERSEN, E.A.; NEVA, F.A.; OSTER, C.N. \& BOGAERT DIAZ, H. - Specific inhibition of lymphocytes proliferation response by adherent suppressor cells in diffuse cutaneous leishmaniasis. New Engl. J. Med., 306: 387-392, 1982.

32. PIRMEZ, C.; YAMAMURA, M.; UEYMURA, K. et al. - Cytokine patterns in the pathogenesis of human leishmaniasis. J. clin. Invest., 91: 1390-1395, 1993.

33. RUSSELL, D. \& ALEXANDER, J. - Effective immunization against cutaneous leishmaniasis with defined membrane antigens reconstituted into liposomes. J. Immunol., 140: 1272-1279, 1988.

34. SADICK, M.D.; HEINZEL, F.P.; HOLADAY, B.J. et al. - Cure of murine leishmaniasis with anti-interlukin 4 monoclonal antibody. Evidence for a $\mathrm{T}$ cell dependent, interferon mechanism. J. exp. Med., 171: 115-127, 1990.

35. SCOTT, P.; PEARCE, E.; NATOVITZ, P. \& SHER, A. - Vaccination against cutaneou leishmaniasis in a murine model. II. Immunological properties of protective and nonprotective subfractions of a soluble promastigote extract. J. exp. Med., 168: 16751684, 1987.

36. SCOTT, P. - The role of Th1 and Th2 cells in experimental cutaneous leishmaniasis. Exp. Parasit., 68: 369-372, 1989

37. SCOTT, P. - IFN-g modulates the early development of Th1 and Th2 responses in murine model of cutaneous leishmaniasis. J. Immunol., 147: 3149-3155, 1991.

38. SHAW, J.J. \& LAINSON, R. - Leishmaniasis in Brasil. X. Some observations on intradermal reactions to different trypanosomatid antigens of patients suffering from cutaneous and mucocutaneous leishmaniasis.Trans. roy. Soc. trop. Med. Hyg., 69: 323-335, 1975.

39. STENGER, S.; THURING, H.; ROLLINGHOFF, M. \& BOGDAN, C. - Tissue expression of inducible nitric oxide synthase is closely associated with resistance to Leishmania major. J. exp. Med., 180: 783-793, 1994.

40. SYPEK, J.P.; CHUNG, C.L.; MAYOR, S.E.H. et al. - Resolution of cutaneous leishmaniasis: interleukin 12 initiates a protective $\mathrm{T}$ helper type 1 immune response. J. exp. Med., 177: 1707-1802, 1993.

41. TAFURI, W.L.; TAFURI, W.L.; BARBOSA, A.J.A. et al. - Histopathology and immunocytochemical study of type 3 and type 4 complement receptors in the liver and spleen of dogs naturally and experimentally infected with Leishmania (Leishmania) chagasi. Rev. Inst. Med. trop. S. Paulo, 38: 81-89, 1996.

42. TITUS, R.G.; SHERRY, B. \& CERAMI, A. - Tumor necrosis factor plays a protective role in experimental murine leishmaniasis. J. exp. Med., 170: 2079-2104, 1989.

Received: 11 August 1998

Accepted: 01 July 1999 